Удк 37.02:378.4(477-81)

Микола Лазарєв

Сумський державний педагогічний університет імені А. С. Макаренка

ORCID ID 0000-0002-6352-6435

Олена Лазарєва

Харківський національний педагогічний

університет імені Г. С. Сковороди

ORCID ID 0000- 0003-4385-0139

DOI 10.24139/2312-5993/2019.08/248-259

\title{
ДІАЛОГІЧНИЙ ПОТЕНЦІАЛ ЕВРИСТИЧНОӦ ОСВІТИ В УМОВАХ ІНФОРМАЦІЙНОГО СУСПІЛЬСТВА
}

Сучасне інформаційне суспільство принципово відрізняється від інших типів соціальних утворень і тому вимагає рішучої заміни авторитарної, антидіалогічної педагогіки на творчу, демократичну педагогіку евристичного діалогу. у статті розглядаються випробувані в експериментальній роботі інноваційні технології евристичної освіти на основі співтворчості викладача і студентів, які сприяють освоєнню й застосуванню майбутніми вчителями евристичного діалогу - основи інноваційної освіти інформаційного суспільства, вагомого чинника творчої самореалізації особистості.

Ключові слова: інформачійне суспільство, евристична освіта, технології евристичної освіти, евристичний діалог, майбутній учитель, співтворчість викладача і студентів, самореалізація особистості.

Постановка проблеми. Сучасне інформаційне суспільство принципово відрізняється від інших типів соціальних утворень, що існували в людській історії, і тому вимагає суттєвого оновлення традиційного педагогічного мислення, існуючих освітніх практик. Насамперед, це стосується необхідності рішучої заміни авторитарної, антидіалогічної педагогіки, яка й досі залишається реальністю на освітньому полі, протистоїть творчій, демократичній філософії постійного евристичного діалогу в навчанні й вихованні. На сьогодні такий діалог має стати одним із головних маркерів інформаційного суспільства, яке пов'язує за допомогою новітніх засобів, насамперед, інтернетних мереж, тисячі організацій, культурних та освітніх установ, мільйони людей, часто не готових до гуманістичного, життєтворного, конструктивного діалогу.

Філософія і педагогіка освіти постіндустріальної, інформаційної ери розглядають принцип і способи діалогізму як неодмінну життєв потребу людини й суспільства, як умову для інтенсивного формування творчого, вільного від будь-яких поневолень і шаблонів філософського та педагогічного мислення, справді гуманістичних відносин демократичної держави і людини, керівника і підлеглих, наставника й учнів. 
Аналіз актуальних досліджень. У процесі аналізу філософських та психолого-педагогічних праць із проблеми діалогу й діалогізації освіти виявлено, що діалог, особливо творчого, евристичного кшталту, 3 прадавніх часів Сократа, Аристотеля, Квінтіліана розглядався як необхідний та ефективний інструмент навчального процесу. Основоположник евристичної освіти геніальний грецький філософ Сократ вважав, що навчання як пізнавальний процес пошуку й побудови знань має розпочинатися з виявлення сфери невідомого, незнаного, яке конче необхідного всім учасникам навчального процесу. А діалог як комплекс запитань і відповідей - провідний компонент будь-якого результативного навчання. Згодом саме сократичний діалог як метод навчання Сократа, пройшовши різні трансформації, але не втративши першоджерельної сутності, став провідним компонентом сучасної евристичної освіти.

Вивчені філософські і педагогічні дослідження наголошують на пріоритеті діалогічних форм і методів освіти, тому що «перенесення за «банківською системою» власного знання своїм учням» (Фрейре, 2004, c. 53), панування передавального, монологічного характеру змісту освіти неефективне для розвитку особистісного потенціалу учня чи студента: постійна зовнішня дія не розвиває їхню продуктивну діяльність, а, навпаки, сковує її, утруднює розвиток закладених із дитинства культурних, психологічних, фізичних можливостей розвитку, не підтримує індивідуальність, сприяючи навчанню всіх за однаковим зразком, без урахування домінуючих мотивів і здібностей кожного учня (Н. Барбаліс, П. Фрейре, В. Беспалько, В. Лозова, В. Паламарчук, А. Хуторськой).

Одночасно монологічний характер освіти не $\epsilon$ ефективним чинником охорони здоров'я школяра. Зростання питомої ваги змісту предметів при «передавальному» типі навчання означає посилення тиску на особу учня ззовні, а, звідси - зростання його психічних і соматичних захворювань (Коротяєв). Аналіз наукових досліджень свідчить, що діалог в освіті $\epsilon$ сутнісною основою розвитку особистості того, хто навчається, і стає головним компонентом інносаційної особистісно орієнтованої освіти, зокрема, освіти евристичної (Є. Бондаревська, А. Король, Б. Коротяєв, С. Кульневич, С. Курганов, В. Лозова, О. Савченко, А. Хуторськой та ін.). Зокрема, академік НАПН України О. Савченко розглядає навчальний діалог не як звичайний обмін запитаннями - відповідями, а як взаємодію суб'єктів освітнього процесу, що може розвиватися в різних напрямках: учитель - учень, учень учні, учень - тексти, учень - комп'ютер тощо (Савченко, 2012). Разом із тим, діалог в освіті, діалогічна складова й діалогічний потенціал евристичної освіти вимагають нових теоретичних і методичних досліджень у багатьох аспектах, зокрема, щодо раціонального поєднання монологічних і діалогічних методів на різних етапах навчального процесу, особливостей застосування технологій діалогічної взаємодії освітніх суб'єктів тощо. 
Мета статті - виявити на теоретичному і технологічному рівнях нові характеристики й можливості формування евристичного діалогу як невід'ємної складової евристичної освіти.

Методи дослідження: аналіз, порівняння, узагальнення, систематизація, історико-генетичний, парадигмальний, синергетичний методи для дослідження можливостей діалогічних технологій в евристичній освіті.

Виклад основного матеріалу. Проведені в нашій науковій школі дослідження здійснювалися з позицій філософії освіти нової доби глобальної інформатизації, пов'язаної із залученням інформаційнокомунікаційних технологій (IKT), і з позицій досліджень педагогічної науки особливостей і проблем інноваційної евристичної освіти та її технологій.

Виявлено, що сучасна стратегія освітніх перетворень має включати розробки умов і способів оптимального й гармонійного використання перевірених наукою і практичним досвідом інноваційних принципів та методів освіти в тісній взаємодії з новими і вдосконаленими освітніми технологіями. Тому стратегія сучасної освітньої модернізації має бути зумовлена необхідністю розв'язати суттєві суперечності між освітою як усе більш технологізованим процесом комп'ютерної доби і освітою посиленого творчо-гуманістичного виховання гармонійної, різнобічно розвиненої й конкурентоздатної особистості, готової до самоосвіти, самозростання і самореалізації в умовах інформаційного суспільства впродовж життя. Така загальна стратегія модернізації освіти включає, безумовно, перехід від освіти авторитарної й монологічної до освіти творчо-діалогічної, тобто освіти евристичної з потужною її складовою - евристичним діалогом у всіх її провідних структурах.

У процесі тривалих і системних досліджень різних типів інноваційної освіти і ї̈ численних технологій ми переконалися, що діалогічна складова евристичного навчання й виховання, насамперед, компетентний, доброзичливий евристичний діалог, являє собою вирішальний чинник евристичної освіти, яка реально ставить у центр своєї уваги активного, небайдужого вчителя (викладача) і такого самого небайдужого, а затим і активного до навчання учня (студента). Але реальна діалогізація як основна природна сутність людиноспрямованої і людиноцентрованої евристичної освіти починається, як не дивно, не з мотивації уваги учнів та впровадження непростих технологій діалогічних відносин і взаємодій. 3'ясовано, що такий процес зароджується з професійного і морального впливу самого педагога, який оволодів особистісно-діалогічним стилем поведінки, стосунків, діяльності і здатен створити атмосферу не формального, а духовного спілкування, коли педагог розуміє внутрішній стан юних співрозмовників, «тут і тепер» і входить у світ їхніх переживань і прагнень, актуалізує та задовольняє потреби в повазі, у сподіваннях кожного з них, визнає реально достойність, здібності, потужні перспективи юних вихованців, розкриває для них на початку роботи нове, цікаве, несподіване, але довгоочікуване 
(Лазарєв, 2016). Проведене дослідження переконало, що першорядна й вирішальна якість евристичного діалогу (як прояв взаєморозуміння та успішної взаємодії) народжується не в його змісті і формі, а поза ними, у духовних і моральних надрах самої особистості. Тому і силу, і слабкість діалогічної спроможності суб'єктів освіти варто шукати передусім у здобутках моральної й духовної культури педагога та його співрозмовників, співшукачів наукової істини.

По суті означені якості і дії професійного педагога i $\epsilon$ проявом справжньої, дієвої, конструктивної, а не абстрактної любові до людини, зокрема, підростаючої особистості - єдності глибокої поваги, довіри, піклування, підтримки й високої вимогливості до вихованця, які $з$ особливою прозорістю і безперечною доказовістю доводив своєю працею, тонкими діалогічними стосунками з вихованцями і всім своїм життям національний педагогічний геній Антон Семенович Макаренко, а за ним і ціла когорта українських науковців та освітян, тисячі його прихильників майстрів педагогічної справи.

Етичну й духовну основу педагогічного діалогу настійливо та послідовно обстоював і впроваджував в освітянське життя Василь Олександрович Сухомлинський. Осмислюючи його думки щодо потужних можливостей мудрої бесіди-діалогу вчителя й учнів (Сухомлинський, 1977), порівнюючи це 3 власною педагогічною практикою, все більше переконуєшся: справжній навчальний чи виховний діалог, що справляє глибинний вплив на душу, розум і серце дитини чи юнака, може здійснити лише педагог із багатим запасом духовних, моральних, естетичних сил, з талантом доброти, самовідданості, любові до дітей, тобто справжня Особистість. Якщо цього немає, не допоможуть жодні найтонші техніки і прийоми педагогічного впливу.

Якщо слідом за А. Макаренком ми називаємо таку діалектично суперечливу якість названого підходу, як єдність глибокої поваги й високої вимогливості до особистості колеги, учня, студента чи будь-кого з наших співрозмовників, то маємо розглядати цю якість як критерій, що неодмінно вимагає своїх більш детальних характеристик для певного рівня реалізації особистісного підходу. Критерії при цьому розглядаються як узагальнені характеристики тієї чи іншої якості, а необхідні для них показники - як деталізація, конкретизація, опредметнення названої якості. Виходячи з цієї позиції, можна, приміром, критерій «єдність поваги й вимогливості» конкретизувати такими, зокрема, показниками, як прояв педагогом глибокої поваги, насамперед, до самого себе, почуття власної гідності, яка синтезується, здається, з протилежною якістю - непідробною скромністю, самокритичністю, здібністю радіти успіхам іншого, зосереджувати увагу, перш за все, не на своїх, а на достоїнствах іншого - колеги, товариша, вихованця, на їхніх позитивних звершеннях. 
І тут по-новому розуміється в сучасному контексті гуманістичної освіти думка А. Макаренка про підхід «до людини з оптимістичною гіпотезою, хай навіть і з деяким ризиком помилитися» (Макаренко, 1960), про вміння спиратися на кращі, а не гірші людські якості. Тільки тоді виникають ланки повноцінного діалогу-спілкування, діалогу-співтворчості: взаємоповага, взаєморозуміння, взаємопідтримка, взаємопритяжіння і, нарешті, результативна вершина евристичного діалогу і всієї евристичної освіти - потужна евристична взаємодія учасників освітнього процесу з метою творчої самореалізації, тобто практичного створення омріяного і значимого для них освітнього продукту - твору, навчального чи професійного, проекту, приладу, навчального модуля, нової технології задуманої спільної творчої справи тощо.

у здійснених нами дослідженнях з'ясовано, що для діалогу евристичного кшталту як плідної взаємодії людей між собою, людей із відмінними інформаційними джерелами та знаряддями праці виступає неодмінна загальна особливість - мотивована творча діяльність, індивідуальна й групова чи колективна. Виявлено, що творча діяльність в освіті об'єднує різнорівневі за складністю типи творчості - аналітичнопошукову, трансформувальну, реконструктивну, конструктивну, креативну, а також різнозмістові її види - дослідно-наукову, художню, технічну, прикладну тощо (Лазарєв, 2016, с. 249-251). Саме творча діяльність у навчанні й вихованні - різних ступенів і видів - стає ефективним притягальним, мотивуючим, мобілізуючим чинником для активної діалогічної співпраці й діалогічної взаємодії дітей та юнацтва. Вони охоче йдуть назустріч із контактним, терплячим, оригінальним і креативним наставником, бо юні душі завжди готові пірнути у світ евристичних пошуків, якщо вони пропонуються в умовах психологічної безпеки, довіри, комфорту емоцій. Не забудьмо, що творчість як створення нового була і $\epsilon$ для юних первинною діяльністю, тобто більш привабливою, приємною, захоплюючою, ніж робота вторинна - копіювання, заучування, переказ, повторення (Ж. Ж. Руссо, Г. Сковорода, Л. Толстой, В. Сухомлинський). Творча діяльність, загальна для дітей і дорослих, тобто співтворчість, $\epsilon$ найкращою умовою цілісного евристичного діалогу з високим проявом сутнісних сил особистості.

У процесі здійснених нашою науковою школою експериментальних досліджень (О.Кривонос, А. Крівшенко, О. Лазарєва, О. Нефедченко, І. Проценко, А. Уварова та ін.) знайшла підтвердження гіпотеза про те, що майбутній учитель в умовах інформаційного суспільства оволодіє розвинутими вміннями евристичного навчального діалогу на високому або достатньому рівні, якщо в освітньому процесі реалізувати необхідні педагогічні умови. По-перше, це чітка й постійна орієнтація на загальну мету національної освіти - досягнення творчої самореалізації підростаючої особистості, - представлену в Національній доктрині розвитку освіти України до 2025 року та інших державних документах з модернізації освітнього 
процесу. По-друге, це глибоке освоєння принципів і методів інноваційної, людиноцентрованої евристичної освіти, епіцентром якої має бути гуманістичний, вільний, паритетний, але обов'язково компетентний, творчий і конструктивний, тобто евристичний діалог усіх суб'єктів освіти. По-третє; це створення й використання комплексу діагностичного інструментарію для моніторингу, самооцінки й оцінки рівнів освоєння майбутнім учителем умінь евристичного навчального діалогу в освітньому процесі. Тільки за таких умов можливе досягнення мети національної освіти в постмодерному, цифровому, інформаційному суспільстві - сформувати готовність і здатність дитини, підлітка, юнака до творчої самореалізації, тобто до особистісного й соціального самозростання, самовдосконалення власних сутнісних сил (потреб, волі, творчих здібностей, умінь, життєвих цінностей). Це реально тільки у процесі евристичного діалогу, тобто глибинної, значимої для особистості тісної взаємодії з іншими людьми, колективами, організаціями, сучасними засобами друкованої і цифрової інформації та контролю. Успішність такої самореалізації постіндустріальне, інформаційне суспільство визначає прагматично й конкретно - наявністю в потрібній кількості та якості зовнішніх і внутрішніх соціально значимих, інноваційних творчих продуктів.

Евристичний діалог у вищій школі, як з'ясували проведені дослідження нашої наукової школи (М. Лазарєв, М. Білоцерковець, Н. Громова, І. Зайцева, Л. Крівшенко, О. Лазарєва, О.Нефедченко, І.Проценко) - це паритетна, інтенсивна й постійна співтворчість викладача і студентів, під час якої ініціюється діяльність останніх із виявлення невідомого і вибудови цілісної групи сутнісних евристичних запитань для знаходження нової істини, створення освітнього продукту у формі нових знань, умінь, технологій діяльності. Такий діалог на рівнях викладач-студент, студент-викладач, студент-студенти, студент-посібник (підручник), студент-цифрова інформація тощо сприяє виявленню недостатніх знань, успішній самореалізації особистості, націлює її на постійне самовдосконалення особистісних якостей і професійних умінь оригінально й критично мислити, бачити проблеми, запитувати, щоб пізнати нове, незнане й невідоме, на основі цього створювати власний освітній продукт - основний компонент самореалізації.

У формуванні вмінь застосування евристичного діалогу у професійній підготовці майбутніх учителів важливе місце відводиться вмінням майбутнього вчителя навчати дітей розмірковувати, ставити сутнісні запитання, знаходити й будувати відповіді на них. Щоб навчити учнів і студентів цим важливим і незамінним діалогічним умінням уперше розроблена, апробована й задіяна в освітню практику цілісна система навчання вмінь запитальної діяльності, тобто формування в учнів і студентів здатності ставити суттєві пізнавальні запитання при евристичному здобуванні всіх типів знань - описових, пояснювальних, прогностичних, під час реалізації різнорівневих видів евристичної діяльності - аналітико-пошукової, 
реконструктивної, конструктивної, креативної. Виявлено, що оволодіння вміннями ставити системну низку проблемних та евристичних запитань, знаходити на них адекватні відповіді прискорюють розвиток мовленнєвої й мовної культури, образного, логічного, дослідницького і критичного мислення (В. Лозова, К. Лазарєва). Майбутній педагог на заняттях і під час педагогічної практики за допомогою розвинутих умінь запитувати й відповідати цілеспрямовано оволодівав евристичним діалогом, діалоговою культурою, новими технологіями евристичного навчання, створенням проблемних ситуацій, організацією самостійної праці учнів на фронтальному рівні і в умовах роботи інтерактивних груп тощо. Майбутній наставник вчився застосовувати методи і прийоми дослідницького підходу до непростих для дітей, але цікавих явищ за допомогою порівнянь, співставлень, асоціацій та аналогій, створення й застосування «батарей» пізнавальних евристичних запитань (М. Лазарєв, Л. Крівшенко). Дослідники означеної проблеми все більше переконувалися самі й переконували своїх колег, що вміння поставити систему адекватних запитань - не просто фрагмент діалогічної взаємодії, це становить основу, епіцентр, становий хребет евристичного діалогу, який, у свою чергу, стає специфічною основою евристичної освіти. У такому разі сама евристична освіта, евристичне навчання перетворюються в сучасних умовах тотальної, глобальної інформатизації і технологізації в найефективніший і найощадливіший спосіб здобутя справжньої загальної та професійної освіченості підростаючого й дорослого населення.

Для успішної реалізації означених педагогічних умов у проведеній експериментальній роботі забезпечувалася відповідна психологопедагогічна підготовка викладачів до впровадження технологій евристичної освіти. Ця підготовка здійснювалася на кафедрах як фахового, так і психолого-педагогічного профілю, і передбачала підвищення професійного інтересу до досліджуваної проблеми й компетентності викладачів в оволодінні теорією і технологіями евристичного навчання взагалі та евристичного діалогу зокрема.

Ефективною формою фахової підготовки майбутніх учителів до освоєння й застосування евристичного діалогу в навчальній і професійній діяльності стали лекції «прямої дії». В експериментах було застосовано авторські варіанти такої лекції на основі методик, запропонованих професорами Б. Коротяєвим і М. Лазарєвим. Як підтверджують результати експериментальної роботи, під час лекції прямої дії студенти постійно і творчо включаються в інноваційну педагогічну діяльність, опановують вміннями вести евристичний навчальний діалог, оскільки стають не пасивними (зовнішніми) спостерігачами, а активними й безпосередніми учасниками разом із викладачем пошуку, осмислення та переосмислення нових наукових знань, систематизації, узагальнюючих висновків щодо їхньої цінності і практичного застосування. Практика проведення лекцій 
«прямої дії» розкрила й позитивні риси сучасних студентів покоління Z (підвищену здатність швидко орієнтуватися в безмежному інформаційному океані і знаходити потрібне), і типові недоліки в їхній пізнавальнопрофесійній сфері (недостатня для значної частини студентства сконцентрованість на теоретичному матеріалі, нерозвинуті мотиви та вміння заглибитися на потрібний час у науковий текст, вчитатися й перечитати його, щоб зробити правильні практичні та теоретичні висновки). Саме розроблена нами гнучка технологія лекцій прямої дії, коли текст лекцій заздалегідь надається студентам для попереднього вивчення, викладач зосереджується на мотивації й постановці проблемних питань і парадоксальних ідеях та фактах науки, а окремі творчі групи готуються звітувати на лекції перед усіма конспектом окремих блоків лекції і самостійними узагальненнями. Така технологія реально створювала евристичний діалог продуктивного i професійного спрямування, активізувала творче й критичне мислення студентів, сприяла неодноразовому заглибленню у пласти непростого теоретичного матеріалу, створювати власні узагальнення, висновки, народжувати й формулювати нерозв'язані, але важливі освітні проблеми тощо.

Щоб студент досяг мети (створення своїх перших професійних продуктів уже під час «лекції прямої дії»), необхідна копітка й систематична робота справжнього педагога-професіонала - досвідченого майстра, переконаного і послідовного гуманіста, який захоплений своєю справою, робить її блискуче, з професійною легкістю, насолодою і одночасно завжди здатний терпляче, з любов'ю, справжньою, непідробною повагою самовіддано надихати і навчати своїх молодих колег.

Студенти за рекомендаціями викладача, який проводив лекції прямої дії, самостійно після занять у кабінетах кафедр і лабораторіях вивчали невеликий обсяг рекомендованих джерел, пов'язаних із опрацьованою лекцією, готували власні короткі рецензії, резюме на прочитані статті, розділи наукових праць, створювали відповіді на конкретні евристичні запитання, поставлені на лекції викладачем. Характерно, що перед проведенням практичного заняття чи семінару за рахунок годин для самостійної роботи, запланованих для студентів, проводилися залікові колоквіуми для невеликих груп - з 4-6 осіб - для діалогової конкретної співпраці, заліку результатів самостійної роботи з матеріалами лекції і рекомендованими джерелами. Так формувалася неперервна система поглибленої роботи над провідними смисловими компонентами теоретичної дисципліни, з'ясовувалися рівень освоєння основного матеріалу на лекційних заняттях і в процесі самостійної роботи, готовність майбутніх учителів до обов'язкового створення запланованих освітніх продуктів.

Необхідним елементом експериментального навчання культури евристичного діалогу стала практика публічного захисту на семінарських і 
практичних заняттях власних творчих продуктів, створених у діалогічній взаємодії з товаришами при постійному зверненні до інформаційних ресурсів Інтернету. Продукти індивідуальної і групової творчості демонструвалися в аудіовізуальних форматах безпосередньо на заняттях та оцінювалися згідно з освоєними критеріями опонентами, експертами і викладачем.

В експериментальній роботі наукової школи випробувано нову форму організації педагогічної практики студентів як заздалегідь підготовленої і практично задіяної проектно-дослідної студії досвідчених майстрів педагогічної справи і майбутніх учителів. Основу такої роботи складало створення у спільній взаємодії професійно-творчих продуктів: модульних розробок системи уроків із певного фаху, оригінальних сценаріїв виховної творчої справи, результатів експерименту з реалізації евристичних освітніх технологій. Здобутий досвід в експериментальному закладі освіти виявив, що в продуктивній, творчій співпраці конче зацікавлені не тільки студенти, а й вчителі, які переконалися, що розбудовча робота з педагогічною молоддю, завзяті дискусії з майбутніми вчителями щодо створення й реалізації інноваційних освітніх проектів надають і молоді, і майстрам справжнього натхнення, переконаності в значимості та привабливості педагогічної праці. Керівництво експериментального закладу - ССШ № 25 м. Суми (директор учитель-методист Л. В. Голуб, їі заступники й одночасно керівники окремих напрямів експериментальної роботи - вчителі-методисти Н. М. Синяговська, Л.М.Крівшенко), учителі-експериментатори відзначали активний внесок студентів і викладачів педуніверситету у зміст і результати здійснюваного фундаментального педагогічного експерименту. Чимало спільних науковометодичних розробок учителів і студентів Сумського педуніверситету стали дійсно інноваційним проривом у створенні оригінальних моделей евристичного навчання, справжньою окрасою фонду методичного кабінету закладу - кращого в місті Суми.

Спільна праця викладачів, студентів університету, педагогів закладу освіти очевидно висвітлили не тільки позитивні результати об'єднаних сил закладів вищої і середньої освіти в успішній реалізації значимого та актуального для міста і області педагогічного експерименту, але й виявив суттєві і досі не вирішені проблеми, що стосуються якості підготовки майбутнього вчителя - майстра і творця.

Сучасний навчальний процес ще не став, але має стати основною пізнавально-творчою (евристичною) діяльністю всіх його суб'єктів (учнів, студентів, педагогів). Конкретно - це освоєння процедур самостійної пошукової (знаходження нового до вже освоєного), реконструктивної (створення нових знань із уже відомих фрагментів), креативної (створення принципово нового і значимого для особистості продукту). Репродуктивна діяльність (запам'ятовування правил, законів, формул, алгоритмів) підпорядкована пізнавально-творчим (евристичним) процедурам, кінцевою 
метою яких є створення нових особистісно значимих для учня (студента) освітніх продуктів. Означені освітні продукти (твори, проекти, розповіді, статті, рецензії, сюжетні сценарії, серії пізнавальних евристичних запитань, власних визначень, висновків, узагальнень тощо) і $\epsilon$ конкретними показниками успішності пізнавально-творчої і професійної самореалізації учня і студента. Тому й оцінювання кожного має відбуватися в основному не за озвученими знаннями правил, положень, запам'ятованих цифр і фактів, а за створеними особистістю цілісними освітніми продуктами, де й використано необхідні елементи знань та вмінь.

Висновки. Освіта стає справді евристичною і результативною за головної умови - досягнення пізнавально-творчої, доброзичливої, майстерної діалогічної взаємодії наставника та учнів, викладача і студентів. А це реально, якщо, насамперед, працюючий і майбутній педагог оволодіють культурою сучасного евристичного діалогу - цивілізованого, гуманістичного і конструктивного, подолають основну біду діалогу традиційного, коли запитує педагог, а учні приречені тільки відповідати, не маючи ні прав, ні вмінь самим ставити власні запитання. Наші дослідження, роботи науковців і вчителів (Н. Барбаліс, П. Фрейре, В. Лозова, А. Сбруєва, О. Козлова, М. Білоцерковець, К. Лазарєва, Н. Громова, І. Проценко, І. Зайцева, Л. Крівшенко, Т. Плохута, Н. Усенко та інші) безперечно доводять необхідність спеціального навчання евристичного діалогу учнів і студентів, зокрема, освоєння останніми основ запитальної діяльності (бажань та вмінь ставити пізнавальні запитання на всіх етапах навчання, конструювати за допомогою системи запитань необхідні освітні продукти, створювати серію запитань для успіху дискусій, диспутів, діагностики результатів діяльності). Сьогодні у складному, суперечливому світі ризиків і непередбачуваного майбутнього будь-яку складну й значиму для нас проблему в побуті, виробництві, освіті можна розв'язати лише за допомогою постановки ретельно складеної системи сутнісних запитань (достатніх за кількісними і якісними показниками), за підтримки творчої і конструктивної евристичної взаємодії - пускових механізмів успішного виявлення суттєвих суперечностей та їх подальшого розв'язання.

Перспективним залишається розв'язання означених та інших суттєвих проблем здійснення справжньої модернізації освіти, перехід ії на евристичні й дослідницькі засади. Педагогічні університети за підтримки Міністерства освіти і науки, НАПН України мають нормативно закріпити в діючих і майбутніх навчальних планах неперервні практики студентів як навчально-дослідницькі студії з педагогіки, педагогічної творчості й майстерності (з виділенням, наприклад, одного дня на тиждень для такої діяльності у кращих базових закладах освіти). Варто твердо закріпити в типових навчальних планах, крім виробничої, також навчально-педагогічну практику з педагогічних дисциплін на 2 і 3 курсах з відривом від навчання протягом двох тижнів, а для бакалаврів і магістрів - передбачити в 
навчальних планах обов'язкові переддипломні наукові студії випускника $з$ вивченням спецкурсів з інноваційних освітніх технологій і підготовкою дипломної науково-експериментальної роботи на базі закладів освіти і науково-дослідних лабораторій.

Думається, що педагог вищої школи вже сьогодні заслужив право на більшу увагу до умов своєї праці, на узаконення в певних межах його спільної і конче необхідної індивідуальної та групової роботи зі студентами в позааудиторний час як важливої частини його академічного навантаження. Це можна здійснити без додаткових витрат академічних годин, за рахунок доцільного розподілу аудиторних і позааудиторних занять. Наприклад, на лекцію витрачати не дві академічних, а одну астрономічну годину, збережений, таким чином, час запланувати на керівництво самостійною роботою студентів - навчальною чи дослідницькою. Без таких заходів будь-які інноваційні технології, зокрема, евристичної діалогічної освіти, не стануть достатньо результативними в підготовці справжнього вчителя-професіонала. Це зайвий раз підтвердив наш досвід і науково-дослідна робота з розробки й упровадження евристичної діалогічної освіти, яка здійснюється більше 15 років.

\section{ЛIТЕРАТУРА}

Коротяев, Б. И. (2013). Взгляд в будущее высшего педагогического образования с позиций теории педагогической философии. Луганск: Изд-во ГУ «ЛНУ имени Тараса Шевченко» (Korotiaiev, В. І. (2013). A look into the future of higher pedagogical education from the standpoint of the theory of pedagogical philosophy. Lugansk).

Лазарєв, М. О. (2016). Педагогічна творчість. Суми (Lazariev, M. О. (2016). Pepagogical creativity. Sumy).

Лазарєв, М., Лазарєва, О. (2018). Особливості і компоненти евристичної освіти у професійній підготовці майбутнього педагога. Науковий часопис НПу імені М.П. Драгоманова. Серія 16. Творча особистість учителя: проблеми теорії $i$ практики: зб. наук. праць, 30 (40), 53-59 (Lazariev, M., Lazarieva, 0. (2018). Features and components of heuristic education in the future teacher's professional training. Scientific journal of NPU named after M. P. Drahomanov, Series 16. Creative personality of the teacher: problems of theory and practice: selected scientific works, 30 (40), 53-59).

Макаренко, А. С. (1960). Сочинения в семи томах, т. 7, с. 299-300. (Makarenko, A. S. (1960). Works in seven volumes, vol. 7, p. 299-300).

Нефедченко, О. І. (2017). Сократівська діалогічна евристика та їі розвиток у зарубіжній та вітчизняній освіті. Педагогічні науки: теорія, історія, інновачійні технології, 132145 (Nefedchenko, O. I. (2017). Socratic dialogical heuristics and its development in foreign and native education. Pedagogical sciences: theory, history, innovative technologies, 132-135).

Савченко, О. Я. (2012). Дидактика початкової освіти. К.: Грамота (Savchenko, О. Үа. (2012). Didactics of elementary education. K.: Gramota).

Сухомлинський, В. О. (1977). Вибрані твори в п'яти томах. Т. 5, с. 160-167 (Sukhomlynskyi, V. O. (1977). Selected works in five volumes. Kyiv. Vol. 5).

Фрейре, П. (2004). Педагогіка свободи: етика, демократія і громадянська мужність. К.: Вид. дім «КМ Академія» (Freire, Р. (2004). Pedagogy of freedom: ethics, democracy and civil courage. Kyiv). 
Burbules, N. C. (1996). Postmodern Doubt and Philosophy of Education. Philosophy of Education. Philosophy of Educational Society. Alven Neiman: Urbana.

\section{PEЗЮME}

Лазарев Николай, Лазарева Елена. Диалогический потенциал эвристического образования в информационном обществе.

Современное информационное общество принципиально отличается от других типов социальных образований и поэтому требует решительной замены авторитарной, антидиалогичной педагогики на творческую, демократическую педагогику эвристического диалога. В статье рассматриваются испытанные в экспериментальной работе инновационные технологии эвристического образования на основе сотворчества преподавателя и студентов, которые способствуют освоению и применению будущими учителями эвристического диалога - основы инновационного образования информационного общества, весомый фактор творческой самореализации личности.

Ключевые слова: информачионное общество, эвристическое образование, технологии эвристического образования, эвристический диалог, будущий учитель, сотворчество преподавателя и студентов, самореализация личности.

\section{SUMMARY}

Lazariev Mykola, Lazarieva Olena The dialogical potential of heuristic education in an information society.

The modern information society is fundamentally different from other types of social entities and therefore requires a decisive replacement of authoritarian, antidialogic pedagogy, which still resists creative, democratic pedagogy of heuristic dialogue. Today, such a dialogue should become one of the main markers of the information society, which connects with the help of the newest means, first of all Internet networks, thousands of organizations, cultural and educational institutions, millions of people, often not ready for a humanistic, constructive dialogue.

The authors define heuristic dialogue in higher education as a parity, intensive and constant co-creation of the teacher and students, where students should identify the unknown and build a coherent group of essential heuristic questions for finding new truth and creating educational products. Such dialogue at the levels of teacher-student, studentteacher, student-student, student-textbook, student-digital information contributes to identification of insufficient knowledge, successful self-realization of the personality, directs it at constant self-improvement of personal and professional qualities.

Innovative techniques of heuristic education tested in experimental work are considered in the article. These techniques contribute to the development and application of heuristic dialogue by future teachers in educational and professional activity: lectures of "direct action", interactive cooperation in the creation of educational products, presentation and protection of educational projects, techniques for questioning skills development, techniques for design studies of master teachers and future educators and so on.

The authors emphasize the need for significant improvement of the work's organization of the teacher of the pedagogical university on the guidance of independent students' work, construction of continuous pedagogical students' practice.

Key words information society, heuristic education, techniques of heuristic education, heuristic dialogue, future teacher, co-creation of teacher and students, selfrealization of the personality. 